\title{
The Use of Realistic Mathematics Education Theory for Designing an Algebra Learning Sequence: The Case of Linear Equations in One Variable
}

\author{
Dian Usdiyana ${ }^{1}$, Al Jupri ${ }^{2}$, Ririn Sispiyati ${ }^{3}$ \\ \{dianusdy@upi.edu ${ }^{2}$, aljupri@upi.edu² ririnsispiyati@upi.edu ${ }^{3}$ \} \\ Departemen Pendidikan Matematika, Universitas Pendidikan Indonesia ${ }^{123}$
}

\begin{abstract}
This research aims to design an algebra learning sequence on the topic of linear equations in one variable - which was taught in Junior High School. We used design research method to do this, and preliminary design phase in particular. First, we designed a sequence of daily life problems in order for students can be familiar with this. This sequence of problems was used for designing a learning sequence. Next, we designed a sequence of learning according to the theory of Realistic Mathematics Education as this theory provides meaningful mathematics for students. Finally, we discussed the design to obtain final learning sequence for a teaching experiment. We consider that the result of the learning design is better than the conventional learning sequence, and it is more meaningful for students.
\end{abstract}

Keywords: Realistic Mathematics Education, Linear Equations in One Variable, Design Research.

\section{Introduction}

Linear equation in one variable is one of algebraic topics which are taught for students in junior high school. This topic should be mastered by students, because this topic is a prerequisite for other algebra topics, such as quadratic equations and system of linear equations in two variables [1]. According to previous relevant research [2], however, Indonesian students are still encounter difficulties in this topic.

Taking the above into account, we have conducted a research-reported here-on designing an algebra learning sequence on the topic of linear equations in one variable. The design was based on the theory of realistic mathematics education (RME). We use three didactical principles of the RME theory: the reality principle, the level principle, and the intertwinement principle [3]. The reality principle means that mathematics learning starts from meaningful problems; the level principle means that in the process of learning mathematics students pass various understanding from context-related solutions to acquiring insight into relationships between concepts and strategies; and the intertwinement principle means that mathematical content domains such as number, algebra and geometry are considered as integrated rather than as isolated mathematical topics [4]. 


\section{Methods}

This research used a design research method, which includes three phases, namely developing a preliminary design, conducting teaching experiments, and conducting a retrospective analysis [5],[6]. In this article, we report the result of the initial design phase carried out in three steps. To do so, first, we conducted a literature review on Indonesian mathematics textbooks for junior high school, research results on students' difficulties on linear equations in one variable, and the theory of realistic mathematics education. Next, we designed a learning sequence on the introduction of linear equations in one variable according to the first step. Third, through focus group discussion, we revise the initial design. The result of this revision is reported in this current article.

\section{Results and Discussion}

The design that we made are for two lessons. The first lesson is for introducing the idea of linear equation in one variable, and the second lesson is for strengthening the skill for solving linear equations in one variable. Figure 1 and Figure 2 present typical problems used in the first lesson. Figure 3 shows typical problems presented for the second lesson.

Consider the following:

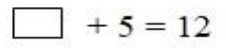

Based on the above sum, please complete the following table.

\begin{tabular}{|c|c|}
\hline$\square$ & $\square+5=\ldots$ \\
\hline 2 & $2+5=7$ \\
\hline 3 & $3+5=8$ \\
\hline & \\
\hline & \\
\hline & \\
\hline & \\
\hline
\end{tabular}

Fig. 1. Introducing the idea of an equation. 


\begin{tabular}{|c|c|}
\hline \multirow{2}{*}{\multicolumn{2}{|c|}{$\begin{array}{l}\text { Consider the following expression. } \\
\qquad \begin{array}{l}25-x=8 \\
\text { Complete the following table and find the value of } x \text {. }\end{array}\end{array}$}} \\
\hline & \\
\hline$x$ & $25-x=.$. \\
\hline 4 & 21 \\
\hline 5 & 20 \\
\hline 6 & \\
\hline 8 & \\
\hline 11 & \\
\hline 15 & \\
\hline 17 & \\
\hline 19 & \\
\hline
\end{tabular}

Fig. 2. Simple linear equation in one variable.

Figure 1 shows a problem that relate between arithmetic which was taught in primary school and the idea of an equation solving. This typical problem becomes a foundation for students to the idea of finding a solution of an equation. From the perspective of RME theory, this problem is designed according the principles of reality and intertwinement [3],[4]. By doing substitution, a student is expected to find 7 as the solution of the problem.

After students understand the idea of an equation solving by doing the problem shown in Figure 1, the students are then given the problem shown in Figure 2. This problem shows similar idea with the idea of Problem 1, but here the box is replaced by the variable $x$. By doing similar thing, namely doing substitution, the students are expected to be able to solve the linear equation. From the perspective of the realistic mathematics education theory this problem applies the level principle because the problem has a similar context with the problem 1 which has more concrete character [3],[4].

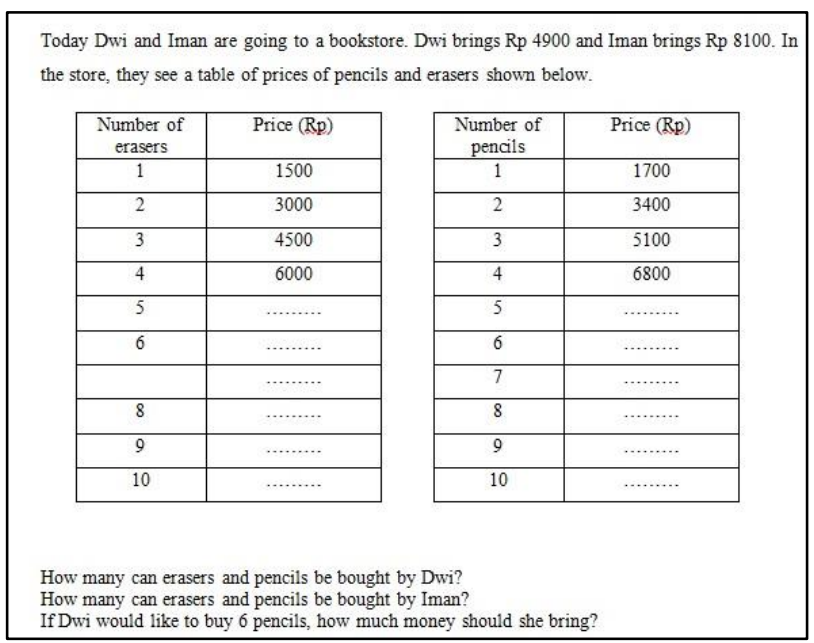

Fig. 3. Application of the idea of simple linear equation in one variable. 
Figure 3 shows how the idea of an equation solving as learned in the first lesson is then applied to solve daily life problems in the second lesson. The use of daily life problems applies the principle of reality [3],[4]. In this way, students have strong foundation to solve word daily life problems. In fact, in this second lesson, other application problems are given to students with the following two reasons: to apply the previous concepts learned in the first lesson, and to emphasize more understanding and ability to solve word daily life problems. An example of other word problems given in the second lesson is shown in Figure 4.

Figure 4 shows an application of the linear equation in variable for solving geometry problem. From the perspective of the RME theory, this problem uses the intertwinement principle [3],[4].

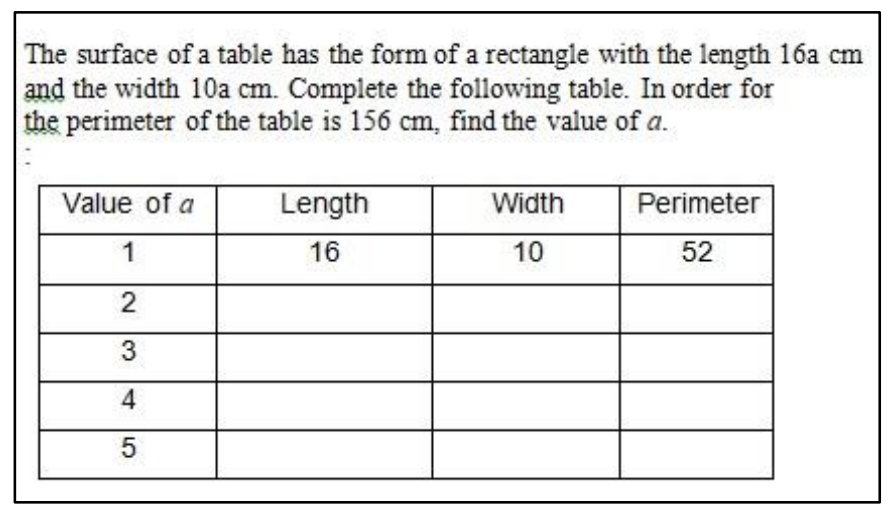

Fig. 4. Application of the linear equation in one variable.

\section{Conclusions}

Based on previous section, we draw the following two conclusions. First, the realistic mathematics education theory is fruitful for designing an algebra learning sequence, and the learning sequence of linear equations in one variable. The three principles of the RME theory that prove to be useful in this case include the reality, the level, and the intertwinement principle. Second, what we have done and discussed in the previous section are our expectation and predictions about the learning process that will be experienced by students if they are taught with this learning material. Therefore, to check whether our predictions are correct, for further investigation, we need to implement this learning sequence in an actual learning and teaching process. Even if our design seems similar to conventional design, we argue that our design is more meaningful for students because the sequence follows the principles of RME theory.

Acknowledgments. This study was funded by Kementerian Riset, Teknologi, dan Pendidikan Tinggi Republik Indonesia through Penelitian Terapan Unggulan Perguruan Tinggi research scheme, year 2019. 


\section{References}

[1] Kemendikbud.: Kurikulum 2013. Kompetensi Dasar: Sekolah Menengah Pertama (SMP)/Madrasah Tsanawiyah (MTs). Jakarta: Kementerian Pendidikan dan Kebudayaan. pp. 1-6 (2013)

[2] Jupri, A., Drijvers, P., and Van den Heuvel-Panhuizen, M.: Mathematics Education Research Journal, Vol. 26, No. 4, pp. 683-710 (2014)

[3]. Van den Heuvel-Panhuizen, M., and Drijvers P.: Realistic Mathematics Education edited by S. Lerman (Springer, Dordrecht, Heidelberg, New York, London), pp. 521-525 (2014)

[4] Jupri, A. From geometry to algebra and vice versa: Realistic mathematics education principles for analyzing geometry tasks. In AIP Conference Proceedings, Vol. 1830, No. 1, p. 050001 (2017)

[5] Bakker, A.: Design Research in Statistics Education: On symbolizing and computer tools (Utrecht, the Netherlands: Freudenthal Institute) (2004)

[6] Gravemeijer, K.: Local instruction theories as means of support for teachers in reform mathematics education. Mathematical thinking and learning, Vol. 6, No. 2, 105-128 (2004) 